\title{
Application of a Site-Binding, Electrical, Double-Layer Model to Nuclear Waste Disposal
}
J. F. Relyea
R. J. Silva

September 1981

Prepared for the U.S. Department of Energy under Contract DE-AC06-76RLO 1830

Pacific Northwest Laboratory Operated for the U.S. Department of Energy by Battelle Memorial Institute 


\title{
NOTICE
}

This report was prepared as an account of work sponsored by the United States Government. Neither the United States nor the Department of Energy. nor any of their employees, nor any of their contractors, subcontractors, or their employees. makes any warranty, express or implied, or assumes any legal liability or responsibility for the accuracy completeness or usefulness of any information, apparatus, product or process disclosed, or represents that its use would not infringe privately owned rights.

The views, opinions and conclusions contained in this report are those of the contractor and do not necessarily represent those of the United States Government or the United States Department of Energy.

\author{
PACIFIC NORTHWEST LABORATORY \\ operated by \\ BATTELLE \\ for the \\ UNITED STATES DEPARTMENT OF ENERGY \\ Under Contract DE-AC06-76RLO 1830
}

\author{
Printed in the United States of America \\ Available from \\ National Technical Information Service \\ United States Department of Commerce \\ 5285 Port Royal Road \\ Springfield, Virginia 22151
}

Price: Printed Copy $\$$

$\therefore$ Microfiche $\$ 3.00$

NTIS

-Pages Selling Price

001-025: $\quad \$ 4.00$

026-050 \$4.50

051-075 \$5.25

$076.100 \quad \$ 6.00$

$101-125 \quad \$ 6.50$

$126-150 \quad \$ 7.25$

$151-175 \quad \$ 8.00$

$176-200 \quad 59.00$

$201-225 \quad 59.25$

$226-250 \quad 59.50$

$251-275 \quad 510.75$

$276-300 \quad 511.00$ 
APPLICATION OF A SITE-BINDING, ELECTRICAL, DOUBLE-LAYER MODEL TO NUCLEAR WASTE DISPOSAL

J. F. Relyea

R. J. Silva*

July 1981

Prepared for

the U.S. Department of Energy

under Contract DE-AC06-76RLO 1830

Pacific Northwest Laboratory

Richland, Washington 99352

* Lawrence Berkeley Laboratory University of California

Berkeley, California 94720 



\section{SUMMARY}

A site-binding, electrical, double-layer adsorption model (Davis, James and Leckie 1978) has been applied to adsorption of Cs for both a montmorillonite clay and powdered $\mathrm{SiO}_{2}$. Agreement between experimental and predicted results indicates that $C_{S}^{+}$is adsorbed by a simple cation-exchange mechan ism.

Further application of a combination equilibrium thermodynamic model and site-binding, electrical, double-layer adsorption model has been made to predict the behavior of $U(V I)$ in solutions contacting either the montmorillonite clay or powdered $\mathrm{SiO}_{2}$.

Experimentally determined $U$ solution concentrations have been used to select what is felt to be the best available thermodynamic data for $U$ under oxidizing conditions. Given the existing information about the probable $U$ solution species, it was possible to determine that $\mathrm{UO}_{2}^{+2}$ is most likely adsorbed by cation-exchange at $\mathrm{pH} 5$. At higher $\mathrm{pH}$ values ( $\mathrm{pH} 7$ and 9), it was shown that $\mathrm{UO}_{2}(\mathrm{OH})_{2}^{\circ}$ is probably the most strongly adsorbed $U$ solution species.

It was also found that high $\mathrm{NaCl}$ solution concentrations at higher $\mathrm{pH}$ values lowered $U$ concentrations (either because of enhanced sorption or lowered solubility); however, the mechanism responsible for this behavior has not been determined. 
1 


\section{CONTENTS}

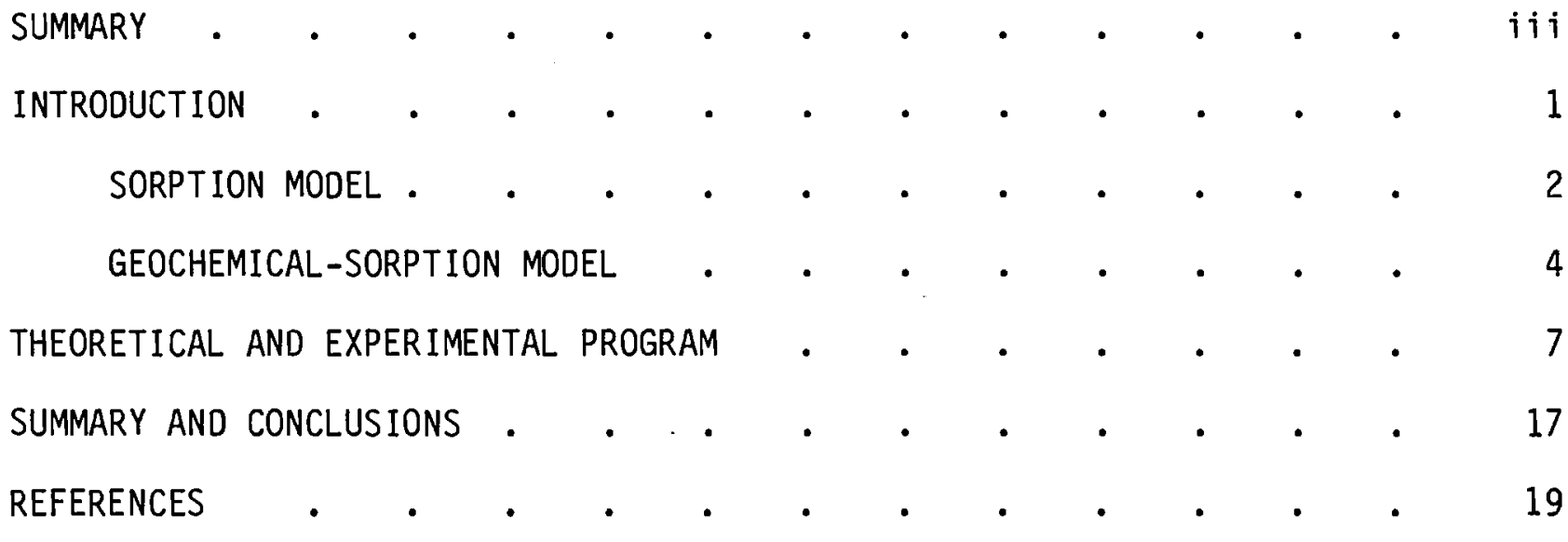




\section{FIGURES}

1 Log Distribution Coefficient (Kd) Versus $\mathrm{pH}$ for $\mathrm{Cs}$ and Belle Fourche Montmorillonite . . . . . • • • • 5

2 Log Distribution Coefficient (Kd) for Cs Adsorption Versus $\mathrm{pH}$ on Quartz . . . . . . . . . . . . 6

3 Log Uranium Solution Concentration Versus pH for Quartz . $\quad 8$

4 Log Uranium Solution Concentration Versus $\mathrm{pH}$ for Belle Fourche Clay • • • • • • • • • • • •

5 Uranium Solution Species in Equilibrium with $\mathrm{UO}_{2}(\mathrm{OH})_{2}(\mathrm{~s})$. $\quad 11$

6 Uranium Solution Species with Initial U Concentration Equal to $1.0 \times 10^{-8} \mathrm{M} . \quad . \quad . \quad . \quad . \quad . \quad . \quad 12$

7 Observed and Predicted $U$ Concentrations After Adsorption

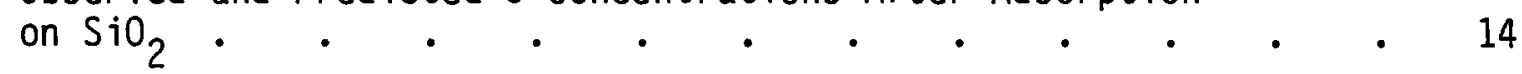

8 Observed and Predicted U Concentrations After Adsorption

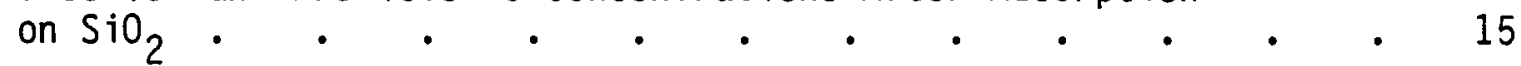





\section{INTRODUCTION}

Mechanistic and empirical sorption models are needed to perform safety assessments and predict the long-term fate of radionuclides in deep geologic nuclear-waste repositories. Defensible empirical data and an understanding of controlling mechanisms are needed to ensure the reliability of model predictions. Values for radionuclide retardation factors selected for existing assessment models are almost always intentionally low (conservative), because retardation processes are not completely understood and few field data are available. Travel times predicted using conservative retardation factors are probably much less than the actual radionuclide travel times (which can be ver ified only on a geologic time scale).

Present methods for the collection of radionuclide retardation data rely on laboratory experiments that are characterized by short times (less than a year), short path lengths (less than a meter) and small samples (less than a kilogram). The applicability of scaling these laboratory results to realistic time frames (thousands of years) and path lengths (kilometers) has not yet been shown.

The degree to which data obtained through laboratory and field tests are applicable to events over centuries can be determined by comparing these results with available equilibrium geochemical models and mechanistic sorption models. Maximal equilibrium radionuclide concentrations can be predicted using sufficient data on 1) site-specific aquifer characteristics (mineralogy, surface area, cation exchange capacity);2) the chemical composition of groundwater, and 3) thermodynamic data describing the radionuclide solution chemistry and solid phases. Any radionuclide sorption on solid surfaces would then result in radionuclide concentrations below the maximal concentration predicted by equilibrium thermodynamic solubility models.

Not all of the needed thermodynamic data are available. However, if the available thermodynamic and mechanistic models are used in conjunction with solubility and retardation experiments, valuable information concerning reactive solute species and retardation mechanisms can be obtained. Expected 
behavior can be compared to behavior observed experimentally to confirm the postulated mechanisms, to indicate another possible mechanism, or to show the need for more study to model the observed behavior.

Conclusive assessments of the safety and performance of nuclear waste repositories cannot be made until more reliable site-specific hydrologic and retardation data are gathered and a better understanding of adsorption mechanisms is acquired. The physical and chemical variability along each sitespecific flow path over the long time frames involved must be addressed to establish the range of conditions that a radionuclide should encounter during transport. With this supporting information, mechanistic and empirical studies of radionuclide behavior, coupled with available thermodynamic predictions, can then be used to provide the needed retardation data.

The objective of this report is to describe the application of a combined geochemical and sorption model to the study of radionuclide retardation mechanisms for the prediction of radionuclide behavior over the long time frames required for isolation of nuclear waste.

SORPTION MODEL

The site-binding, electrical, double-layer model used in this study is described in detail by Silva et a1. (1980) and Davis, James and Leckie (1978). For this reason, the model will be described only briefly in this report.

Most solid materials acquire a surface charge when placed in contact with a polar solvent such as water. The net charge may be positive, negative or neutral (point of zero charge), depending on the nature of the solid and solution compositions, particularly the pH. The most common mechanism for a surface to obtain a net electrical charge is through the uptake or release of potential determining ions on the surface (e.g., $\mathrm{H}^{+}$or $\mathrm{OH}^{-}$). Charged surfaces tend to adsorb ions of opposite charge to maintain electrical neutrality and thus develop an electrical double layer. Permanent charges may also be present on solid surfaces because of isomorphous substitution in the crystal structure, such as $\mathrm{Al}^{+3}$ substituting for $\mathrm{Si}^{+4}$ or $\mathrm{Fe}^{+2}$ for $\mathrm{Al}^{+3}$. The permanent charges 
are treated as ionizable sites in the model presented here. If a surface is assumed to have only one kind of ionizable site, two reactions determine the surface charge:

$$
\begin{aligned}
& \mathrm{SOH}_{2}^{+} \leftrightharpoons \mathrm{SOH}+\mathrm{H}_{\mathrm{S}}^{+} ; \mathrm{Ka}_{1} \\
& \mathrm{SOH} \leftrightharpoons \mathrm{SO}^{-}+\mathrm{H}_{\mathrm{S}}^{+} ; \mathrm{Ka}_{2}
\end{aligned}
$$

where $S$ in the equations refers to the surface to which the oxygen is bonded, and the subscript, $s$, refers to an ion at the surface (but not adsorbed) and differs from an ion in bulk solution by the amount of energy needed to move the charged ion across the difference in electrical potential between the surface and bulk solution. $\mathrm{Ka}_{1}$ and $\mathrm{Ka}_{2}$ are the surface ionization constants for these two dissociation reactions.

Normally, when a supporting electrolyte is present, ions other than $\mathrm{H}^{+}$ balance the surface charge. If the solution contains only $\mathrm{NaCl}$, the reactions describing the cation/anion charge balance are:

$$
\begin{array}{ll}
\mathrm{SO}^{-}+\mathrm{Na}^{+} \leftrightharpoons \mathrm{SO}^{-}-\mathrm{Na}^{+} ; & \mathrm{K}_{\mathrm{Na}}^{+} \\
\mathrm{SOH}_{2}^{+}+\mathrm{Cl}^{-} \leftrightharpoons \mathrm{SOH}_{2}^{+} \mathrm{Cl}^{-} ; & \mathrm{K}_{\mathrm{Cl}}^{-}
\end{array}
$$

The electrical work needed to bring an ion from bulk solution to the charged surface results in a difference in activity for that ion at the two different positions. The model makes this correction so that the reaction constants can be related to quantities measured in solution. In a normal multicomponent groundwater, other cations and anions are found. These may be treated by writing equations similar to (3) and (4).

Exchange reactions such as $\mathrm{Na}^{+}$for $\mathrm{H}^{+}$can then be written as:

$$
\mathrm{SOH}+\mathrm{Na}_{\mathrm{S}}^{+} \leftrightharpoons \mathrm{SO}^{-}-\mathrm{Na}^{+}+\mathrm{H}_{\mathrm{S}}^{+} ; \quad \mathrm{K}_{\mathrm{Na} / \mathrm{H}}=\mathrm{Ka}_{2} \cdot \mathrm{K}_{\mathrm{Na}}^{+}
$$


The constant $\mathrm{K}_{\mathrm{Na} / \mathrm{H}}$ is frequently referred to as the selectivity coefficient. If more than one kind of exchange site exists on the surface, another set of equations similar to Equations (1) through (5) can be added to the model.

The resulting set of equations can then be solved algebraically to predict both the solution concentration and surface concentration for a particular element. If a distribution coefficient ( $K d$ ) is needed, the Kd may be calculated in a straightforward manner once these two concentrations are known. However, the already available solution and surface concentrations may be more valuable for radionuclide transport modeling than the $\mathrm{Kd}$ alone. The use of $\mathrm{Kd}$ in transport modeling is discussed in the WISAP technical progress report for FY-77 (PNL-2642).

Estimates of the surface ionization constants $\left(K_{1}\right.$ and $\left.K a_{2}\right)$ are made from acid and/or base titrations of the adsorbing solids over a suitable range of electrolyte concentrations. Naturally, care must be taken that the $\mathrm{pH}$ range during titration does not extend past the range in which the solid phase is stable. The selectivity coefficients that describe the exchange of one cation (or anion) for another (for example $\mathrm{Cs}^{+}$exchange with $\mathrm{Na}^{+}$) must also be determined experimentally or calculated from existing data for the system of solids and solutions being studied.

GEOCHEMICAL-SORPTION MODEL

Perhaps the most important aspect of this sorption model is that it is compatible with thermodynamic geochemical models. The surface ionization and exchange equations are written in the form of chemical reactions with the ir respective equilibrium constants. At the Lawrence Berkeley Laboratory, this adsorption submodel has been included in MINEQL (a computerized thermodynamic code developed by Westall, Zachary and Morel 1976) so that precipitation, dissolution, complex-ion formation, oxidation-reduction, and adsorption reactions can be considered simultaneously in a single geochemical model. If the initial surface and solution ion concentrations are known, a radionuclide may be added to the system, and its distribution between the solid and solution phases can be predicted. 
Figure 1 shows a comparison between $\mathrm{Cs}^{+} \mathrm{Kd}$ values determined experimentally and those predicted by MINEQL for Belle Fourche clay (a montmorillonite) over a wide range of $\mathrm{pH}$ and $\mathrm{NaCl}$ solution concentrations. The dashed curve was calculated using the activity correction for the difference between bulk solution and surface potentials; the solid line was calculated without the correction. The predicted $\mathrm{Kd}$ values for $\mathrm{Cs}^{+}$exchange with $\mathrm{Na}^{+}$show a good correlation with the experimental data. It can be seen that the inclusion of the activity correction term (dashed line) did little to improve the fit.

Adsorption of $\mathrm{Cs}^{+}$on $\mathrm{SiO}_{2}$ powder is shown in Figure 2. With the batch method used, the relative error for small Kd values is large. Again, the activity correction did little to improve the fit of experimental and predicted results. Below pH 7 the observed and predicted values for Cs sorption on quartz data deviate, but fair agreement is found in the environmentaliy important range, $\mathrm{pH} 7$ to $\mathrm{pH} 10$.

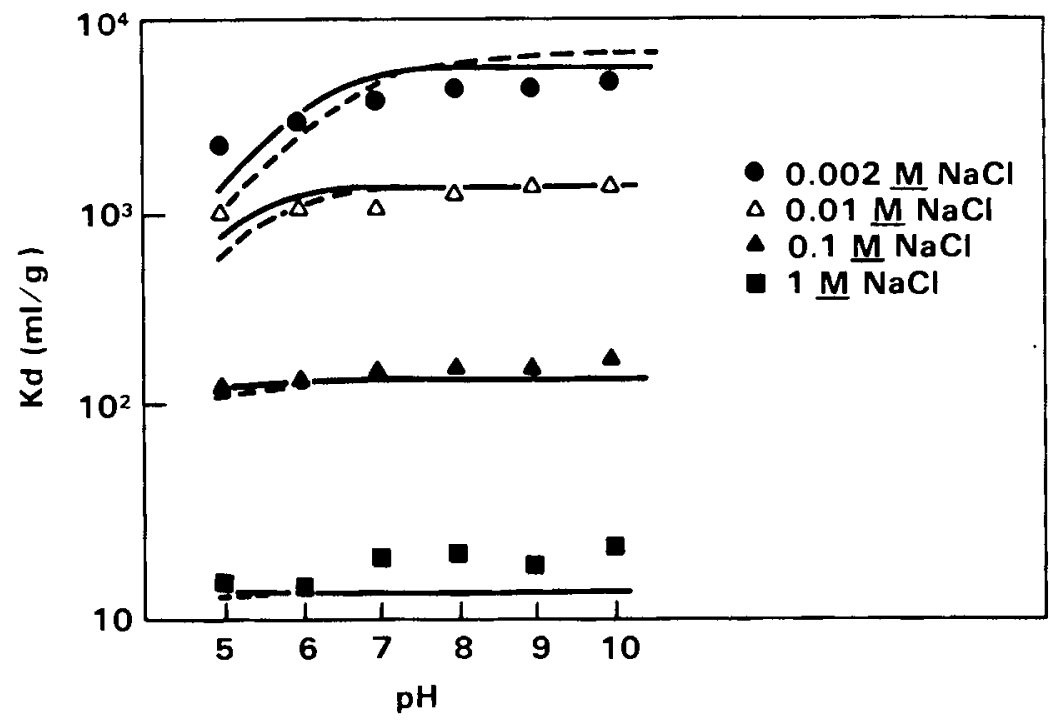

FIGURE 1. Log Distribution Coefficient (Kd) Versus pH for Cs and Belle Fourche Montmorillonite. Initial $\mathrm{Cs}^{+}$concentration $=$ $1.01 \times 10^{-7} \underline{M}$ 

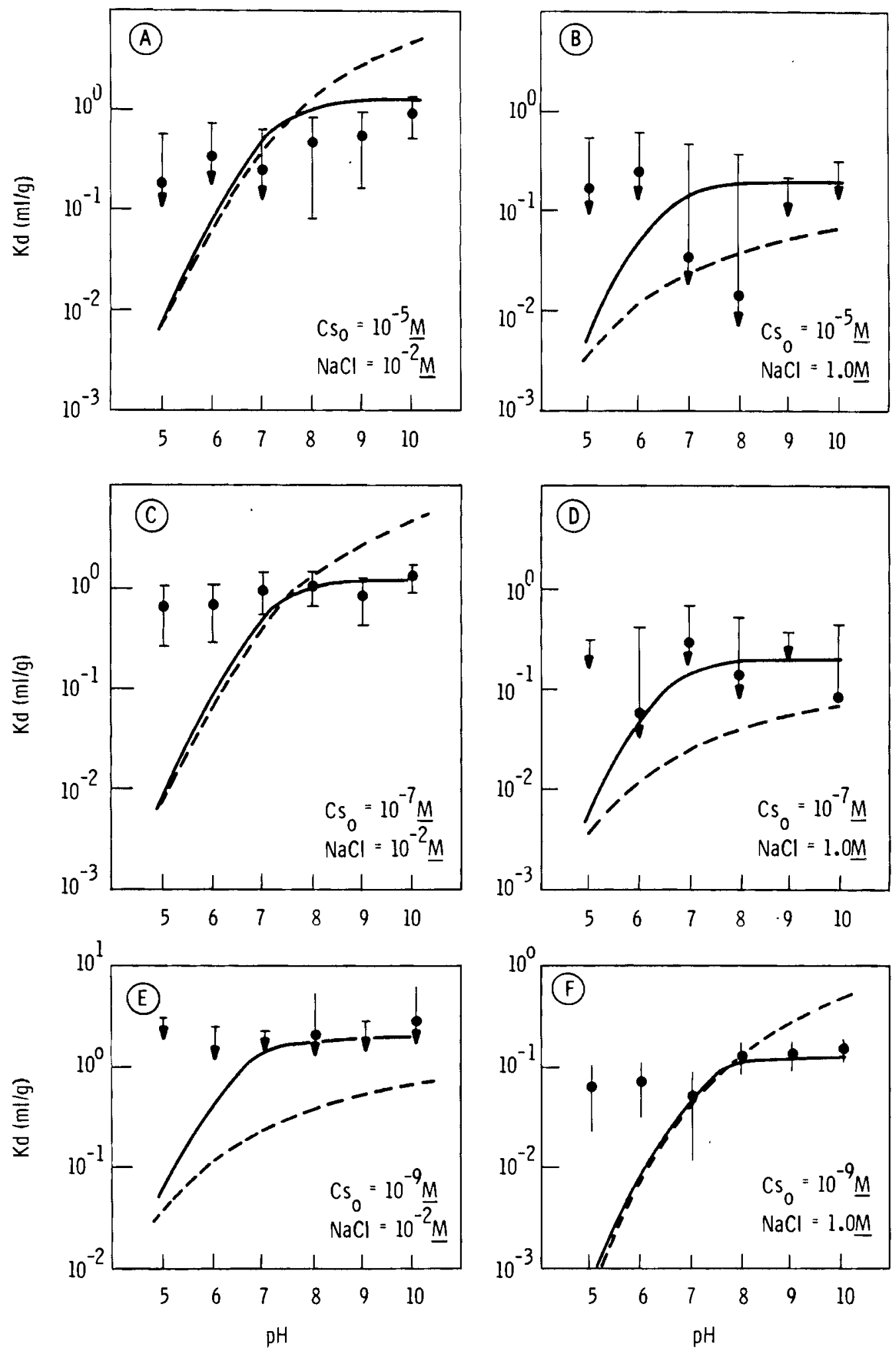

FIGURE 2. Log Distribution Coefficient (Kd) for Cs Adsorption Versus pH on Quartz. Experimental data are shown by the solid points and uncertainty in the measured $K d$ values is shown by the vertical lines. 


\section{THEORETICAL AND EXPERIMENTAL PROGRAM}

Currently, it is believed that sufficient data are available for making solubility and complexation predictions for uranium in the environment. The first step is to verify that predicted solution concentrations and species agree with experimental data. In other words, data from several sources can be compared with experimental results to ensure that the best data are chosen for the thermodynamic data base to be used as input for later mode 1 predictions.

If the thermodynamic model based on solubility and complex formation adequately depicts the solution behavior of a radionuclide, a solid-phase adsorber such as $\mathrm{SiO}_{2}$ or a clay can be added to the system, and the coupled adsorptionthermodynamic model can be verified experimentaliy for that substrate. If the observed solution concentrations do not agree with the predictions after known adsorption mechanisms have been taken into account, additional mechanisms for adsorption or precipitation can then be determined and put into the coupled mode 1 .

Experimental work in progress at Lawrence Berkeley Laboratory (LBL) with $U$ present initially as $\mathrm{UO}_{2}^{+2}$ has been conducted on $\mathrm{SiO}_{2}$ (min-u-sil, a powdered quartz) and Belle Fourche montmorillonite. Solution variables are $\mathrm{NaCl}$ concentration (1.0 $\mathrm{M}, 0.1 \mathrm{M}, 0.01 \mathrm{M}$ and $0.001 \mathrm{M}) ; \mathrm{CO}_{3}^{-2}\left(10^{-4} \mathrm{M}\right.$ and no $\left.\mathrm{CO}_{3}^{-2}\right)$, initial $U 0_{2}^{+2}$ concentration $\left(10^{-\overline{4}} \underline{M}, 10^{-6} \underline{M}\right.$ and $\left.10^{-8} \underline{M}\right)$ and $\mathrm{pH}(5,7$ and 9$)$.

Predictions of total $U$ concentrations were made using the combined adsorption mode 1, MINEQL, with thermodynamic constants from Langmuir (1978) and Lemire and Tremaine (1980). The Lemire and Tremaine data set includes constants for the formation of $\mathrm{UO}_{2}(\mathrm{OH})_{2}^{\circ}$ and $\left(\mathrm{UO}_{2}\right)_{3}(\mathrm{OH})_{7}^{-}$, which are missing in Langmuir's data base. The dashed lines in Figures 3 and 4 are made using Langmuir's data (for $0.01 \underline{\mathrm{M}} \mathrm{NaCl}$ on $\mathrm{ly}$ ), and the solid lines are made with thermodynamic constants from Lemire and Tremaine. Predictions

$\star \mathrm{UO}_{2}(\mathrm{OH})_{2}^{\circ}$ is a neutral solution species not to be confused with the solid phase $\mathrm{UO}_{2}(\mathrm{OH})_{2}(\mathrm{~s})$, which may precipitate. 

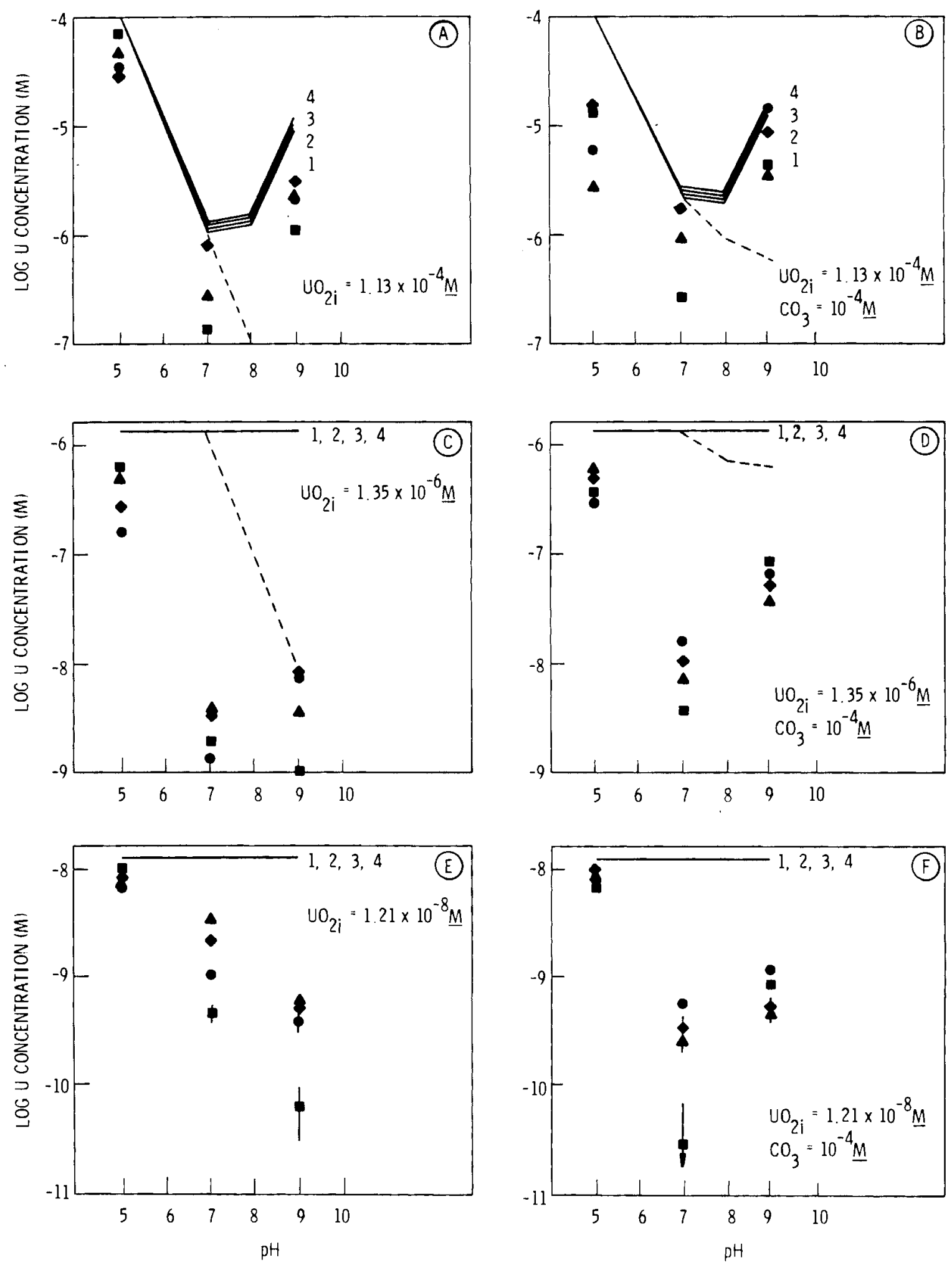

FIGURE 3. Log Uranium Solution Concentration Versus pH for Quartz. Numbers on the solid lines and data points refer to the various $\mathrm{NaCl}$ concentrations: $1 \bullet 0.001 \mathrm{M} \mathrm{NaCl}, 2 \diamond 0.01 \underline{\mathrm{M} \mathrm{NaCl}}, 3 \triangle 0.1 \underline{\mathrm{M}}$ $\mathrm{NaCl}$ and 4 I $\mathrm{M} \mathrm{NaCl}$. 

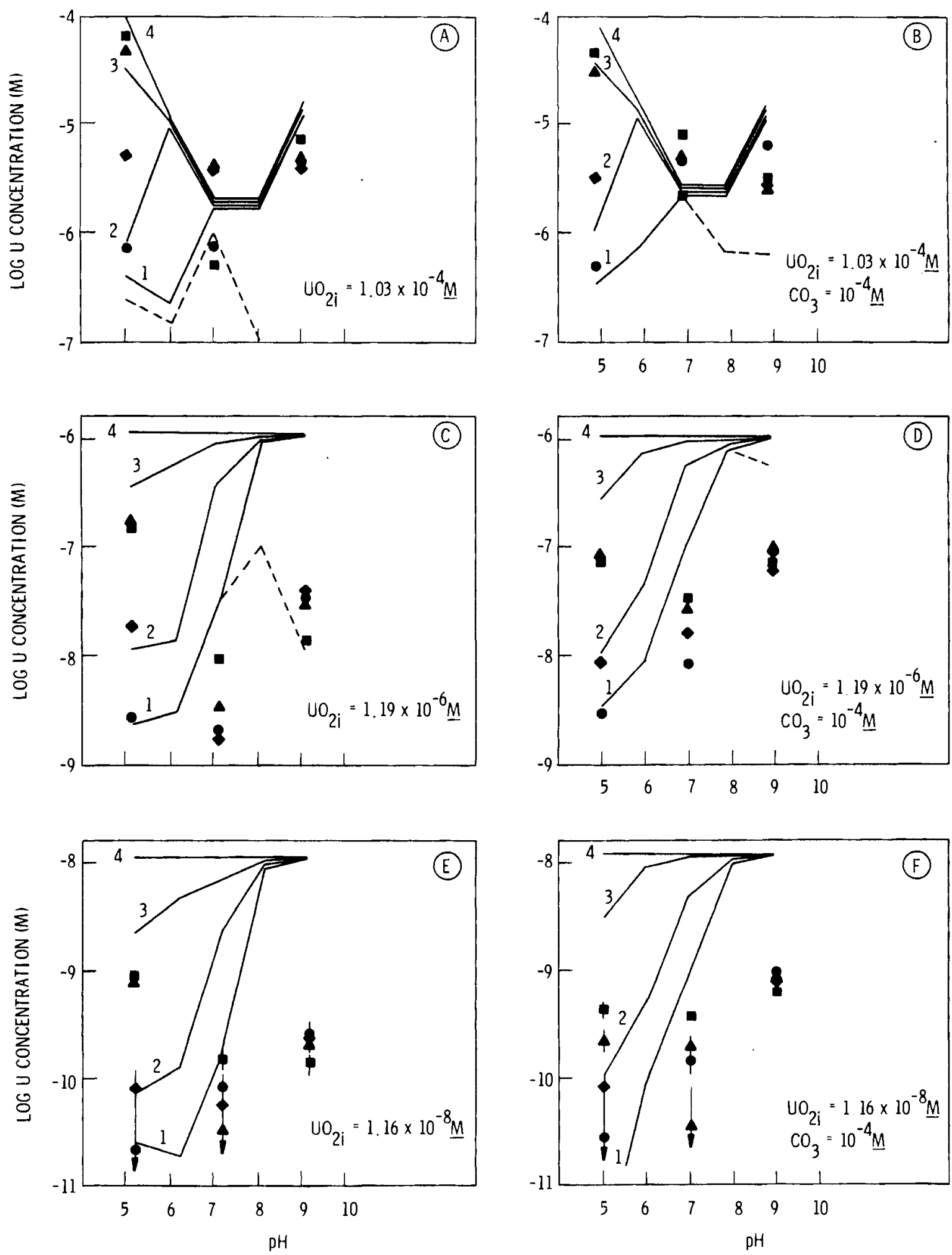

FIGURE 4. Log Uranium Solution Concentration Versus pH for Belle Fourche Clay. Numbers on the lines and data points refer to the various $\mathrm{NaCl}$ concentrations as follows: $1 \bullet 0.001 \mathrm{M} \mathrm{NaCl}, 2 \bullet 0.01 \mathrm{M} \mathrm{NaCl}$, $3 \triangle 0.1 \underline{\mathrm{M} \mathrm{NaCl}}$ and $4 \backsim 1 \underline{\mathrm{M} \mathrm{NaCl}}$. 
were made at discrete values of $\mathrm{pH}(5,6,7,8$ and 9) and joined by straight lines to account for the "kinks" in the predicted curves.

Uranium solubility has not been verified in a separate experiment; however, adsorption of $10^{-4} \mathrm{M} \mathrm{UO}_{2}^{+2}$ by $\mathrm{SiO}_{2}$ was predicted to be negligible. Ten milliliters of $10^{-4} \mathrm{M} \mathrm{UO}_{2}^{+\overline{2}}$ contains one milliequivalent (meq) of $\mathrm{UO}_{2}^{+2}$. Because the powdered quartz has a sorption-site concentration of about 0.02 $\mathrm{meq} / \mathrm{g}$, and on $1 \mathrm{y} 0.1 \mathrm{~g}$ of the quartz was used for sorption in $10 \mathrm{ml}$ of solution, there is an excess of $\mathrm{UO}_{2}^{+}$of about 500 times the theoretical $\mathrm{SiO}_{2}$ sorption capacity. Thus, the predicted concentrations in Figures $3 A$ and $3 B$ are essentially predictions for the solubility of $\mathrm{UO}_{2}(\mathrm{OH})_{2}(\mathrm{~s})$ and may be compared to experimental results for deciding which thermodynamic constants are best suited to model $U$ behavior. In the experimental system used, an initial $\mathrm{UO}_{2}^{+2}$ concentration of $10^{-4} \mathrm{M}$ should cause precipitation of $\mathrm{UO}_{2}(\mathrm{OH})_{2}(\mathrm{~s})$. Between pH 5 and 7 , positively charged $U$ species should be dominant. Between $\mathrm{pH} 7$ and $8, a$ minimum in solution $U$ concentrations should be observed as the neutral species $\mathrm{UO}_{2}(\mathrm{OH})_{2}^{\circ}$ dominates. Above $\mathrm{pH} 8$, the negatively charged species $\left(\mathrm{UO}_{2}\right)_{3}(\mathrm{OH})_{7}^{-}$ gives an increase in $U$ concentration with increasing $\mathrm{pH}$. Experimental results shown in Figures $3 A$ and $3 B$ generally follow this trend (predicted with thermodynamic data from Lemire and Tremaine (1980) shown in Figure 5). It should be noted that the omission of a complex [such as $\mathrm{UO}_{2}(\mathrm{OH})_{2}^{\circ}$ and $\left(\mathrm{UO}_{2}\right)_{3}(\mathrm{OH})_{7}^{-}$from Langmuir's data set] can be as much a problem as an incorrect thermodynamic value. Once the major complex ion species are known (or suspected), efforts may be concentrated on determining the formation constants for those species, and constants for minor species may receive less emphasis.

The effects of $\mathrm{CO}_{3}^{-2}$ on $U$ concentration are seen only at $\mathrm{pH} 9$ because below this $\mathrm{pH}$, most dissolved $\mathrm{CO}_{2}$ is present in the bicarbonate form $\left(\mathrm{HCO}_{3}^{-}\right)$. At $\mathrm{pH} 9$, however, the presence of $10^{-4} \mathrm{M} \mathrm{CO}_{3}^{-2}$ does seem to increase the total $U$ concentration as would be expected with the formation of $\mathrm{UO}_{2} \mathrm{CO}_{3}^{\circ}$.

Adsorption of $\mathrm{UO}_{2}^{+}$was not predicted to be a significant factor in limiting the concentration of $U$ in the presence of $\mathrm{SiO}_{2}$, but adsorption of $\mathrm{UO}_{2}^{+2}$ by the montmorillonite was expected to be significant. When the initial $U$ concentration is undersaturated with respect to $\mathrm{UO}_{2}(\mathrm{OH})_{2}(\mathrm{~s})$, adsorption is predicted to lower the $U$ concentration only in the montmorillonite system at $\mathrm{pH} 5$ and 7 , 


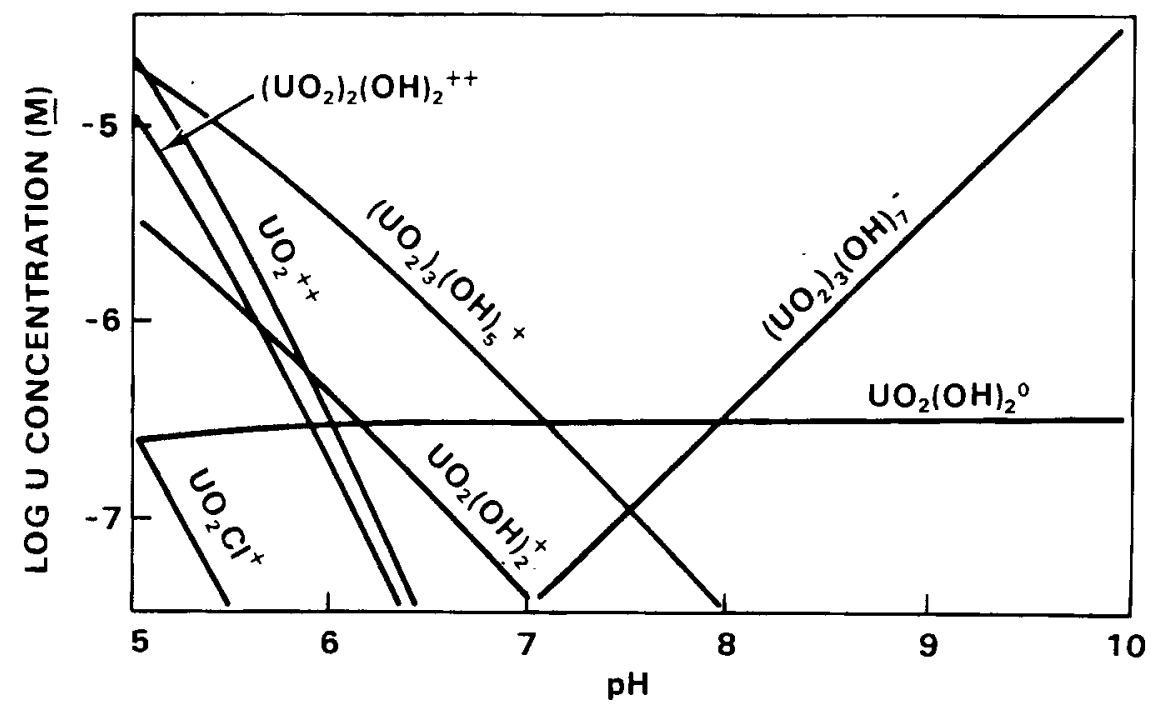

FIGURE 5. Uranium Solution Species in Equilibrium with $\mathrm{UO}_{2}(\mathrm{OH})_{2}(\mathrm{~s})$. Supporting electrolyte is $0.01 \mathrm{M} \mathrm{NaCl}$. Initial $\mathrm{U}$ concentration equal to $1.0 \times 10^{-4} \bar{M}$.

because carbonate solution complexes should predominate at $\mathrm{pH} 9$. Figure 4 shows that an ion exchange adsorption mechanism may be operative at $\mathrm{pH} 5$ in the montmorillonite system. Adsorption at $\mathrm{pH} 5$ is highest when the ionic strength is lowest $\left(10^{-3} \underline{\mathrm{M} \mathrm{NaCl}}\right)$ and when competition between $\mathrm{Na}^{+}$and $\mathrm{UO}_{2}^{+}$for exchange sites is also low. At higher ionic strength $(1.0 \mathrm{M} \mathrm{NaCl}), \mathrm{Na}^{+}$saturates adsorption sites on the clay and $\mathrm{Cl}^{-}$forms a complex ion, $\mathrm{UO}_{2} \mathrm{Cl}^{+}$which should be less competitive with $\mathrm{Na}^{+}$for adsorption sites than $\mathrm{UO}_{2}^{+2}$. Even so, the match between predicted and observed concentrations at $\mathrm{pH} 5$ is not all that great. At pH 7 and 9 there is no match at all between predictions and observed results, suggesting that ion exchange of $\mathrm{UO}_{2}^{+2}$ is not the predominant sorption mechanism at these $\mathrm{pH}$ values.

Similar total $\mathrm{U}$ concentrations were observed at $\mathrm{pH} 7$ and 9 in solutions containing either $\mathrm{SiO}_{2}$ or Belle Fourche montmorillonite. Thus, the results cannot be explained by cation-exchange adsorption of $\mathrm{UO}_{2}^{+2}$ alone. The expected increase of $U$ in solution with increasing $\mathrm{NaCl}$ concentration was not observed. From the above information it appears that a common adsorption mechanism (not ion exchange) is operative in both the $\mathrm{SiO}_{2}$ and montmorillonite systems. 
Thus far it has been assumed for the adsorption model that only the $\mathrm{UO}_{2}^{+2}$ ion is adsorbed. Several $U$ solution species are present and several might be adsorbed to a greater extent than $\mathrm{UO}_{2}^{+2}$. Adsorption of the $\mathrm{UO}_{2} \mathrm{CO}_{3}^{\circ}$ species is not likely because an increase in $\mathrm{CO}_{3}^{-2}$ concentration (Figure 4 ) is found to increase the $U$ solution concentration, indicating that $\mathrm{CO}_{3}^{-2}$ reduces $U$ sorption. Adsorption of $\mathrm{UO}_{2} \mathrm{Cl}^{+}$is not a likely mechanism either, because the $\mathrm{UO}_{2} \mathrm{Cl}^{+}$concentration decreases by a factor of ten for each unit $\mathrm{pH}$ increase, and the chloride complex is negligible at higher $\mathrm{pH}$ values $(>7)$.

In these systems $\left(\mathrm{SiO}_{2}\right.$ and $\left.\mathrm{clay}\right)$, the only remaining $U$ species of any importance are the hydrolyzed forms of $\mathrm{UO}_{2}^{+2}$. Figure 6 shows the dominant solution species with total $U=10^{-8} \underline{M}$. Two complexes of $U$ may be adsorbed: $\mathrm{UO}_{2} \mathrm{OH}^{+}$and $\mathrm{UO}_{2}(\mathrm{OH})_{2}^{\circ}$.

It is not surprising that the dominant adsorption mechanism may change with increasing pH. James and Healy (1972) have shown that adsorption of several cations is abruptly enhanced as hydrolysis occurs and the ionic charge

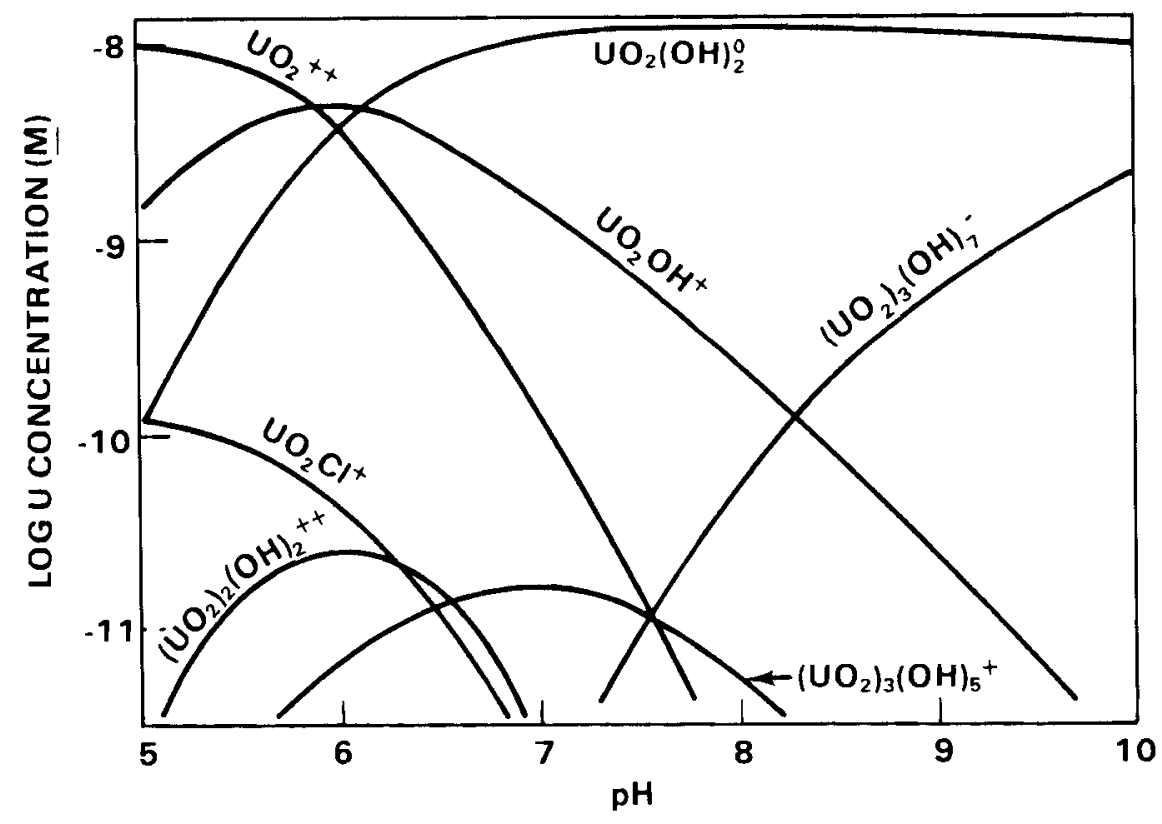

FIGURE 6. Uranium Solution Species with Initial U Concentration Equal to $1.0 \times 10^{-8} \mathrm{M}$. Supporting electrolyte is $0.01 \mathrm{M} \mathrm{NaCl}$. 
of the solute metal is lowered. It has also been suggested that the environment around surface-bound oxygen atoms $\left(-\mathrm{SiO}^{-}\right)$and aqueous $\mathrm{OH}^{-}$groups are similar (Stumm and Morgan 1970). This raises the possibility that a cation may form a surface complex with an $-\mathrm{SiO}^{-}$group analogous to aqueous $\mathrm{OH}^{-}$as the $\mathrm{pH}$ is increased and hydrolysis becomes important. Thus, up to $\mathrm{pH} 5$, ion exchange may be the dominant adsorption mechanism for $\mathrm{UO}_{2}^{+2}$. As the $\mathrm{pH}$ approaches 5.5 to 5.9 , the solution species $\mathrm{UO}_{2}(\mathrm{OH})^{+}$and $\mathrm{UO}_{2}^{+2}$ become equal in concentration. However, the second hydrolys is occurs at only a slightly higher $\mathrm{pH}$ than the first, and $\mathrm{UO}_{2}(\mathrm{OH})_{2}^{\circ}$ soon becomes the dominant species. We might then expect that the mechanism for $U$ adsorption could be the formation of complexes with surface-bound oxygens in competition with hydrolys is complexes formed in solution.

To model the surface complexation adsorption mechanism, an equation for each reaction must be written:

$$
\mathrm{UO}_{2} \mathrm{OH}^{+}+\mathrm{SOH} \leftrightharpoons \mathrm{SO}^{-}-\mathrm{UO}_{2} \mathrm{OH}^{+}+\mathrm{H}^{+} ; \mathrm{K}_{1}
$$

and

$$
\mathrm{UO}_{2}(\mathrm{OH})_{2}^{\circ}+\mathrm{SOH} \leftrightharpoons \mathrm{SOH}-\mathrm{UO}_{2}(\mathrm{OH})_{2}^{\circ} ; \quad \mathrm{K}_{2}
$$

These two equations were included in the model, and the reaction constants $\left(K_{1}\right.$ and $\left.K_{2}\right)$ were varied by trial and error to obtain the best fit to the experimental data. $\log K_{2} \simeq 4$ gave the best fit and $K_{1}$ was of minor importance. The data from $F$ igures $3 D$ and $3 F$ are replotted in Figures 7 and 8 , respectively, and the model predictions for $0.001 \underline{M} \mathrm{NaCl}$ and $1 \underline{M} \mathrm{NaCl}$ as the supporting electrolyte solutions are shown by the solid lines.

The empirical sorption model for $U$ on $\mathrm{SiO}_{2}$ shown in Figures 7 and 8 represents the observed sorption much better than the model used for predictions shown in Figure 3. Results from the empirical model indicate that a neutral species $\mathrm{UO}_{2}(\mathrm{OH})_{2}^{\circ}$ is highly adsorbed by the surface. James and Healy (1975) hypothesized that $\mathrm{Cd}$ adsorption by $\mathrm{TiO}_{2}$ at $\mathrm{pH}$ values above 7 was mainly due to strong adsorption of $\mathrm{Cd}(\mathrm{OH})_{2}^{\circ}$. Schindler et al. (1976) later hypothesized that $\mathrm{Cu}(\mathrm{II}), \mathrm{Cd}(\mathrm{II})$, and $\mathrm{Pb}(\mathrm{II})$ may form bonds with two surface sites 


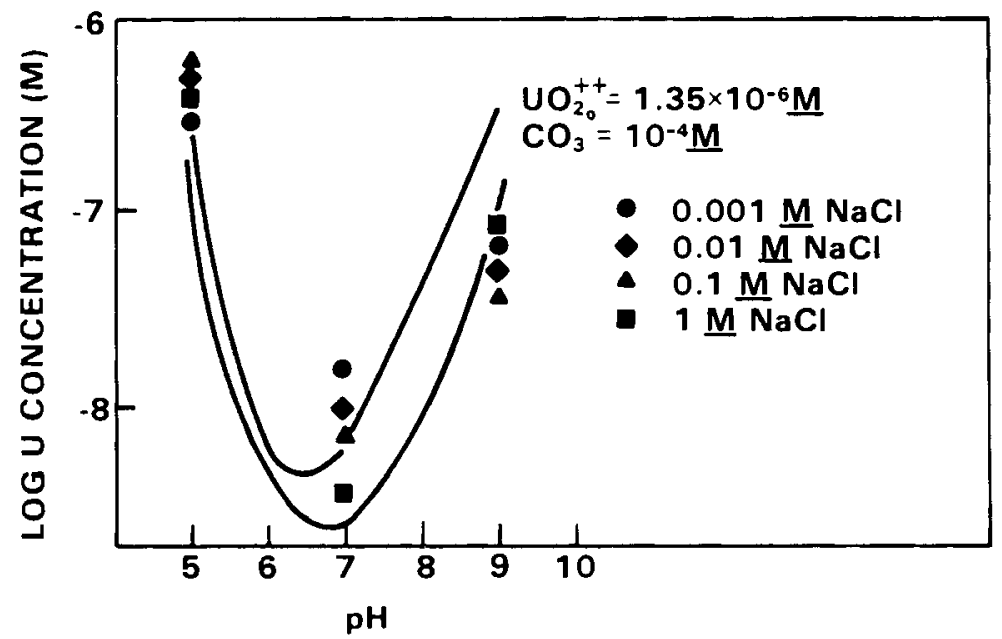

FIGURE 7. Observed and Predicted U Concentrations After Adsorption on $\mathrm{SiO}_{2}$. Data are replotted from Figure 3D. New predictions (solid lines) were made by assuming the major adsorbed species was $\mathrm{UO}_{2}(\mathrm{OH}) \stackrel{\circ}{\text {. }}$

at $\mathrm{pH}$ values where these divalent cations would normally hydrolyze in solution. [The model proposed by Schindler et al. (1976) allows adsorption of the unhydrolyzed divalent cation, but adsorption depends on the hydrolys is constant for that cation.] Davis and Leckie (1978) used the same model (sitebinding, electrical, double-layer) that is used for this work, and found that adsorption of $\mathrm{Ag}(\mathrm{I})$ on amorphous iron oxyhydroxide could be better described if $\mathrm{Ag}(\mathrm{OH})^{\circ}$ and $\mathrm{Ag}^{+}$were both adsorbed than if $\mathrm{Ag}^{+}$alone was assumed to sorb.

Thus, the hypothesis that $\mathrm{UO}_{2}(\mathrm{OH})_{2}^{\circ}$ is the major adsorbed species in this work is not without precedent. The exact mechanism for the extensive adsorption of $\mathrm{U}$ on $\mathrm{SiO}_{2}$ at $\mathrm{pH} 7$ is presently unknown and, as stated by Davis and Leckie (1978), "Careful studies of the kinetics of surface reactions will be necessary to determine whether hydrolys is occurs first in solution or at the surface following adsorption of an aquo metal ion."

Another aspect of $U$ behavior in both the $\mathrm{SiO}_{2}$ and clay system that requires more research is the influence of $\mathrm{NaCl}$ on $U$ concentrations. Complexation by $\mathrm{Cl}^{-}$to form $\mathrm{UO}_{2} \mathrm{Cl}^{+}$and competition with $\mathrm{Na}^{+}$for exchange sites should reduce $U$ adsorption at higher $\mathrm{NaCl}$ concentrations. At $\mathrm{pH} 7$ and 9 in the $\mathrm{SiO}_{2}$ 


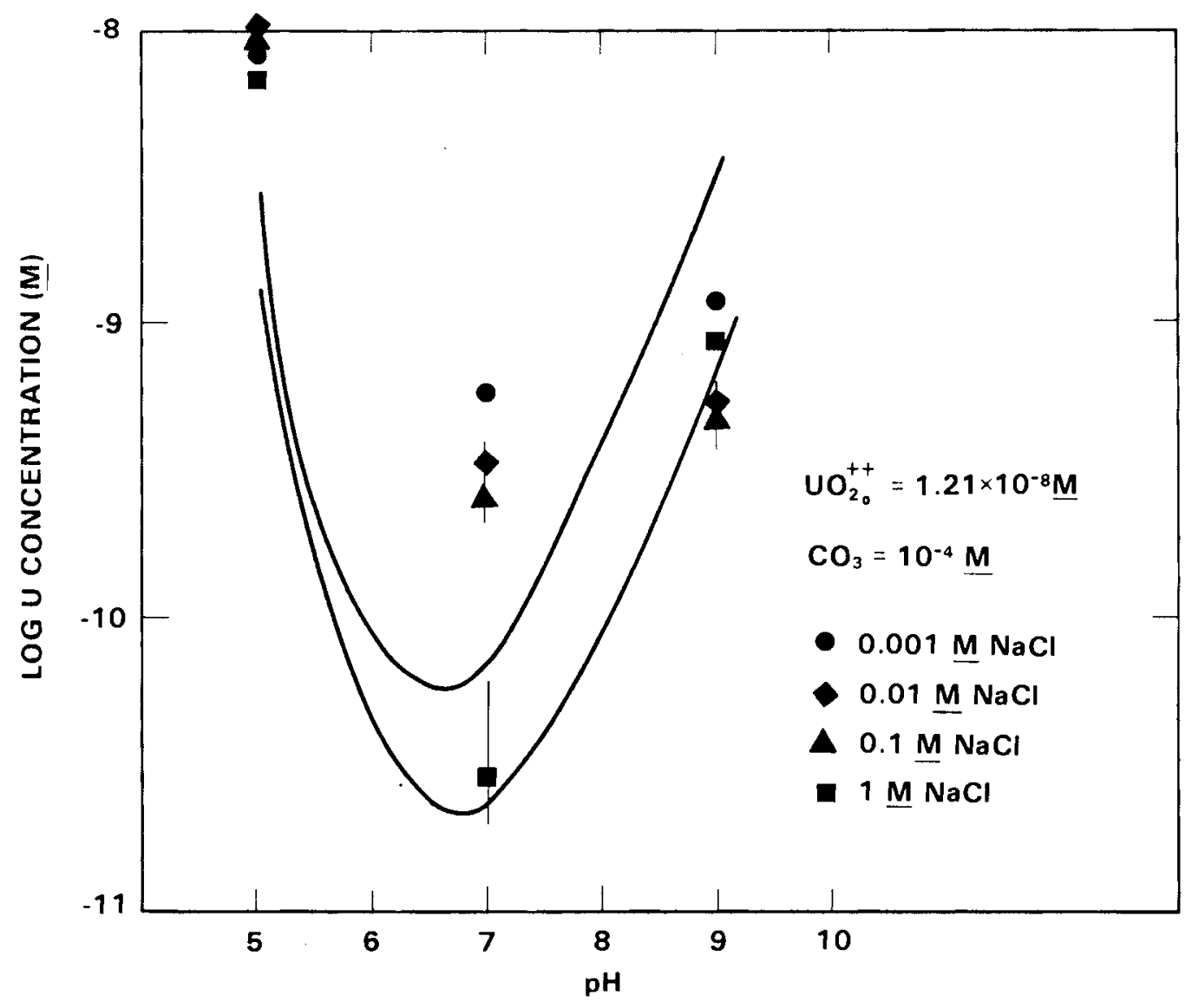

FIGURE 8. Observed and Predicted U Concentrations After Adsorption on $\mathrm{SiO}_{2}$. Data are replotted from $F$ igure $3 \mathrm{~F}$. New predictions (solid lines) were made by assuming the major adsorbed species was $\mathrm{UO}_{2}(\mathrm{OH})_{2}^{\circ}$.

system and at $\mathrm{pH} 9$ with the clay, the higher $\mathrm{NaCl}$ concentrations seem to enhance adsorption of $U$ instead of reducing the adsorption as would be expected. It is possible that dispersion of the suspended particles at low $\mathrm{NaCl}$ concentrations gives high values for $U$ in solution because of adsorbed $U$ on those particles; but, this is unlikely because all samples were filtered through a $0.2-\mu \mathrm{m}$ membrane before counting. It is also possible that a solid phase other than $\mathrm{UO}_{2}(\mathrm{OH})_{2}(\mathrm{~s})$ may limit $U$ solubility in these systems. Rai and Serne (1978) have postulated that $\mathrm{Na}_{2} \mathrm{UO}_{4}$ may control uranium solubility under the conditions here. The data shown in Figures $3 \mathrm{~A}$ and $3 \mathrm{~B}$, however, indicate that $\mathrm{UO}_{2}(\mathrm{OH})_{2}(\mathrm{~s})$ is indeed a likely candidate solid phase that places an upper 1 imit on the $U$ solution concentration. The effect of high $\mathrm{NaCl}$ concentration 
on $U$ concentrations will require further study because of the possibility of a nuclear waste repository being placed in bedded or dome salt. Lowered solubility or enhanced adsorption of $U$ in salt brine or bittern would greatly reduce the release rate of $U$ from a repository and thus lessen the consequences of both $U$ and the long-lived daughter, Ra-226, in the accessible environment. 
SUMMARY AND CONCLUSIONS

The combined use of a equilibrium thermodynamic chemical model and the site-binding, electrical, double-layer adsorption model has led to predictions about dissolved $U$ concentrations following sorption onto a montmorillonitic clay and onto $\mathrm{SiO}_{2}$ from solutions varying from $10^{-8} \underline{M}$ to $10^{-4} \underline{M}$ initial $\mathrm{UO}_{2}^{+2}$ concentrations.

These predictions have been checked experimentally. In the case where $U$ sorption was calculated to be negligible $\left(10^{-4}\right.$ M initial $\mathrm{UO}_{2}^{+2}$ in an $\mathrm{SiO}_{2}$ suspension), the results have served to test the thermodynamic solubility and complexation data base and provide a basis for selecting what is felt to be the best available data.

This approach also aids in determining the conditions for which a simple electrostatic ion exchange mechanism is the dominant adsorption mechanism. When the proposed mechanism is found to be invalid (such as is the case for $\mathrm{UO}_{2}^{+2}$ sorption at $\mathrm{pH} 7$ and 9 ), the chemical model is still a valuable guide for determining what solution species or surface characteristics may be responsible for the unexpected behavior.

It was assumed that the hydrolyzed solution species $\mathrm{UO}_{2} \mathrm{OH}^{+}$and $\mathrm{UO}_{2}(\mathrm{OH})_{2}^{\circ}$ were adsorbed at the higher $\mathrm{pH}$ values. By varying the reaction constants for the surface complexes that might be formed by the two hydrolyzed species, it was found that $U$ sorption could be modeled empirically. The results of the empirical modelling suggest that the neutral species $\mathrm{UO}_{2}(\mathrm{OH})_{2}^{\circ}$ is strongly adsorbed.

High $\mathrm{NaCl}$ concentrations at $\mathrm{pH} 7$ and 9 with $\mathrm{SiO}_{2}$ and at $\mathrm{pH} 9$ with the clay were unexpectedly found to cause lower $U$ solution concentrations, compared to $U$ concentrations in dilute $\mathrm{NaCl}$. The implication is that either $U$ sorption is enhanced or $U$ solubility is lowered in high-ionic-strength $\mathrm{NaCl}$ solutions. Either of these two effects will reduce the hazard of $U$ to the environment in a bedded salt or salt dome repository. Continued efforts are needed to 1) identify and model the mechanism responsible for enhanced sorption of $U$ observed at $\mathrm{pH} \geq 7$, and 2) identify the mechanism responsible for the inverse relationship between solution $\mathrm{NaCl}$ and $U$ concentrations. 
This study is an important step in determining the mechanisms responsible for the adsorption of uranium (as well as plutonium, neptunium and other radionuclides that form oxycations or complex ions with ligands in groundwater). The concept will be extended to other cation-surface complexation reactions in the future.

If the mechanisms that control the solution concentration of a radionuclide are known (e.g., an adsorption or precipitation reaction) and equilibrium expressions for those mechanisms can be written, the concern over short times and path lengths encountered in laboratory experiments can be discounted. As long as the environment is not altered, the equilibrium of a solutionsurface-radionuclide system will not change in time or space, and predictions based on the knowledge of sorption and thermodynamic processes will be invariant. If laboratory experiments using appropriate environmental conditions are performed until equilibrium is attained, then the results should be valid for predicting actual events in the field. 


\section{REFERENCES}

Burkholder, H. C., J. Greenborg, J. A. Stottlemyre, D. J. Bradley, J. R. Raymond and R. J. Serne. 1977. "Waste Isolation Safety Assessment Program: Technical Progress Report for FY-77." PNL-2642, Pac if ic Northwest Laboratory, Richland, Washington.

Davis, J. A., R. 0. James and J. 0. Leckie. 1978. "Surface Ionization and Complexation at the 0xide/Water Interface I. Computation of Electrical Double Layer Properties in Simple Electrolytes." J. Colloid Interface Sci. 63:480-499.

Davis, J. A. and J. O. Leckie. 1978. "Surface Ionizaton and Complexation at the Oxide/Water Interface II. Surface Properties of Amorphous Iron Oxyhydroxide and Adsorption of Metal Ions." J. Colloid Interface Sci. 67: $90-107$.

James, R. 0. and T. W. Healy. 1972. "Adsorption of Hydrolyzable Metal Ions at the 0xide/Water Interface." J. Colloid Interface Sci. 40:65-81.

James, R. O. and T.W. Healy. 1975. "Analysis of Models of Adsorption of Metal Ions at 0xide/Water Interfaces." J. Chem. Soc. Faraday Trans. $59: 142-156$.

Langmuir, D. 1978. "Uranium Solution-Mineral Equilibria at Low Temperatures with Application to Sedimentary Ore Deposits." Geochim et Cosmochim Acta. $42: 547-569$.

Lemire, R. J. and P. R. Tremaine. 1980. "Uranium and Plutonium Equilibria in Aqueous Solutions to $200 \mathrm{C} . " \mathrm{~J}$. Chem. Eng. Data. 25:361-370.

Rai, D. and R. J. Serne. 1978. "Solid Phase and Solution Species of Different Elements in Geologic Environments." PNL-2651.

Schnindler, P. W., B. Furst, R. Dick and P. U. Wolf. 1976. "Ligand Properties of Surface Silanol Groups I. Surface Complex Formation with $\mathrm{Fe}^{3+}, \mathrm{Cu}^{2+}, \mathrm{Cd}^{2+}$ and $\mathrm{Pb}^{2+} . "$ J. Colloid Interface Sci. 55:469-475.

Silva, R. J., L. V. Benson, A. W. Yee and G. A. Parks. 1980. "Theoretical and Experimental Evaluation of Waste Transport in Selected Rocks." In Waste Isolation Safety Assessment Program: Task 4, Third Contractor Information Meeting, Volume 1. J. F. Relyea, Chairman, PNL-SA-8571, Pacific Northwest Laboratory, Richland, Wasington.

Stumm, W. and J. J. Morgan. 1970. "Aquatic Chemistry," Chapter 9, The SolidSolution Interface, Wiley-Interscience, New York.

Westa11, J. C., J. L. Zachary and F. M. M. Morel. 1976. Tech. Note No. 18. Water Quality Laboratory. Dept. of Civil Eng. M.I.T. 


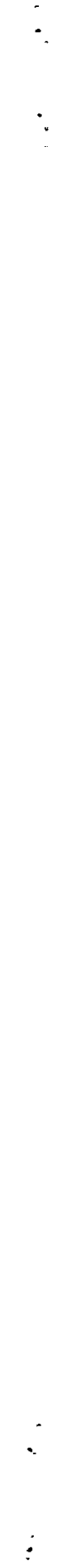




\section{DISTRIBUTION}

No. of

Copies

OFFSITE

A. A. Churm

DOE Patent Division

9800 South Cass Avenue

Argonne, IL 60439

27 DOE Technical Information Center

Don Alexander

U.S. Nuclear Regulatory

Commission

MS 905-SS

High Leve 1 Waste Tech. Development

Washington, DC 20555

Argonne National Laboratory

Reference Library

9800 South Cass Avenue

Argonne, IL 60439

10 Battelle Memorial Institute

Office of Nuclear Waste

Isolation

505 King Avenue

Columbus, $\mathrm{OH} 43201$

Attn: Beverly Rawles

Gary Bea 11

Radian Corporation

8500 Shoal Creek

Austin, TX 78766

Or. John Bird

Geology Department

Corne 11 University

Ithaca, NY 14853
No. of

Copies

Ernest Bondiett $i$

Environmental Sciences Division

Oak Ridge National Laboratory

Bldg. 1505

Oak Ridge, TN 37830

A. Brandstetter

Office of Nuclear Waste Isolation

Battelle Memorial Institute

505 King Avenue

Columbus, $\mathrm{OH} 43201$

Brookhaven National Laboratory

Reference Section

Information Division

Upton, Long Island, NY 11973

Harry C. Burkholder

Office of Nuclear Waste Isolation

Battelle Memorial Institute

505 King Avenue

Columbus, $\mathrm{OH} 43201$

J. L. Burnett

DOE Office of Basic Energy Sciences

Washington, DC 20545

Wayne Carbiener

Office of Nuclear Waste Isolation

Battelle Memorial Institute

505 King Avenue

Columbus, $\mathrm{OH} 43201$

H. Clyde Claiborne

Oak Ridge National Laboratory P.0. Box $X$

Oak Ridge, TN 37830 
No. of

Copies

Peter Columbo

Brookhaven National Laboratory Nuclear Waste Management Group Upton, NY 11973

Carl R. Cooley

DOE Division of Waste Isolation Washington, DC 20545

Jared Davis

U.S. Nuclear Regulatory Commission

Washington, DC 20555

Les Dole

Oak Ridge National Laboratory

P.0. Box X

Oak Ridge, TN 37830

Jim 0 . Duguid

Office of Nuclear Waste

Isolation

Battelle Memorial Institute

505 King Avenue

Columbus, $\mathrm{OH} 43201$

Environmental Protection Agency

Office of Radiation Programs

Technical Assessment Division AW559

Washington, DC 20460

Warren Eister

DOE Division of Waste Isolation

Washington, DC 20545

Bruce R. Erdal

Los Alamos Scientific Laboratory

CNC-11, MS -514

Los Alamos, NM 87545

Sherman Fried

Agronne National Laboratory

9700 South Cass Avenue

Argonne, IL 60439
No. of

Copies

A. Friedman

Argonne National Laboratory

9700 South Cass Avenue

Argonne, IL 60439

Alex Gancarz

Los Alamos Scientific Laboratory

CNC-11, Mailstop 514

Los Alamos, NM 87545

Robert G. Garvin

E. I. duPont deNemours Co.

Savannah River Laboratory

Aiken, SC 29801

Richard L. Hahn

Oak Ridge National Laboratory

P.0. Box $X$

Oak Ridge, TN 37830

R. J. Hall

Office of Nuclear Waste

Isolation

Battelle Memorial Institute

505 King Avenue

Columbus, $\mathrm{OH} 43201$

Mark Harwe 11

P.0. Box 667

Canon Beach, OR 97110

Colin A. Heath

DOE Division of Waste Isolation

Washington, DC 20545

Peter Hoffman

Office of Nuclear Waste

Isolation

$505 \mathrm{King}$ Avenue

Columbus, $\mathrm{OH} 43201$

H. D. Holland

Dept. of Geological Sciences

Harvard University

Cambridge, MA 02138 
No. of

Copies

Norman Hubbard

Office of Nuclear Waste Isolation

Battelle Memorial Institute

505 King Avenue

Columbus, $\mathrm{OH} 43201$

J. K. Johnstone

Sandia Laboratories

Albuquerque, NM 87107

G. R. Kilp

Advanced Energy System Division Westinghouse Electric Corp.

P.0. Box 10864

Pittsburgh, PA 15236

John F. Kircher

Office of Nuclear Waste Isolation

Battelle Memorial Institute

505 King Avenue

Columbus, $\mathrm{OH} 43201$

Lawrence Berkeley Laboratory

Reference Library

University of California

Berkeley, CA 94720

Lawrence Livermore Laboratory

Reference Library

P.0. Box 808

Livermore, CA 94550

Tom Longo

DOE Division of Waste Isolation

Washington, DC 20545

Los Alamos Scientific Laboratory

Reference Library

P.0. Box 1663

Los Alamos, NM 87544

Richard W. Lynch

Manager, Department 4530

Sandia Laboratories

P.0. Box 5800

Albuquerque, NM 87185
No. of

Copies

J. B. Martin

Asst. Director for Radioactive Waste Mgmt. Branch

NRC Division of Materials and

Fue 1 Cycle Facility Licensing

Washington, DC 20555

Martin A. Molecke

Nuclear Waste Experimental

Programs

Division 4512

Sandia Laboratories

Albuquerque, NM 87185

J. E. Monsees

Office of Nuclear Waste

Isolation

Battelle Memorial Institute

$505 \mathrm{King}$ Avenue

Columbus, $\mathrm{OH} 43201$

Jim P. Murray

Harvard University

Pierce $\mathrm{Ha} 11$

Cambridge, MA 02138

Jeff 0 . Neff

DOE Columbus Program Office

505 King Avenue

Columbus, $\mathrm{OH} 43201$

Edward Norr is

Los Alamos Scientific Laboratory

Group CNC-11 MS-514

P.0. Box 1663

Los Alamos, NM 87545

E. J. Nowak

Sandia Laboratory

Division 5824

Albuquerque, NM 87131

Oak Ridge National Laboratory

Central Research Library

Document Reference Section

Oak Ridge, TN 37830 
No. of

Copies

Edward 0'Donne 11

U.S. Nuclear Regulatory

Commission

Office of Standards Development

Washington, DC 20555

W. M. Pardue

Office of Nuclear Waste

Isolation

Battelle Memorial Institute

505 King Avenue

Columbus, $\mathrm{OH} 43201$

George A. Parks

Stanford University

Department of Applied Earth

Sciences

Stanford, CA 94305

L. D. Ramspott

Lawrence Livermore Laboratory

P.0. Box 808

Livermore, CA 94550

Gary A. Robbins

Department of Geology

Texas A\&M University

College Station, TX

R. A. Robinson

Office of Nuclear Waste

Isolation

Battelle Memorial Institute

505 King Avenue

Columbus, $\mathrm{OH} 43201$

Savannah River Laboratory

Reference Library

Aiken, SC 29801

Martin Seitz

Argonne National Laboratory 9700 South Cass Avenue

Argonne, IL 60439
No. of

Copies

\author{
Robert Silva \\ Lawrence Berkeley Laboratory \\ University of California \\ One Cyclotron Road \\ Building 70A/1160 \\ Berkeley, CA 94720 \\ David B. Stewart \\ National Center 959 \\ U.S. Geological Survey \\ Reston, VA 22092
}

H. Weed

Lawrence Livermore Laboratory

P.0. Box 808, MS-L233

Livermore, CA 94550

William B. White

Materials Research Laboratory

Pennsylvania State University

University Park, PA 16802

R. F. Williams

Electric Power Research Institute

3412 Hillview Avenue

P.0. Box 10412

Palo Alto, CA 94303

W. A. Williams

Office of Radiation Programs

Environmental Protection Agency

Washington, DC 20460

Wilste Library

U.S. Nuclear Regulatory

Commission

Washington, DC 20555

T. J. Wolery

Lawrence Livermore Laboratory

P.0. Box 808

Livermore, CA 94550

H. Tom Yolken

National Bureau of Standards

Physics Building/B320

Washington, DC 20234 
No. of

Copies

ONSITE

5 DOE Richland Operations Office

0. J. Elgert

H. E. Ransom

J. J. Schreiber

F. R. Standerfer

M. W. Shupe

5 Rockwe 11 Hanford Operations

G. S. Barney

D. Brown

M. J. Smith

M. I. Wood

B. J. Wood

Hanford Engineering Deve lopment Laboratory

R. J. Cash

48 Pacific Northwest Laboratory

D. J. Bradley

T. D. Chikalla

M. 0 . Cloninger

D. G. Coles

W. J. Deutsch

F. H. Dove

J. H. Jarrett
No. of

Copies

E. A. Jenne

F. N. Hodges

M. R. Kreiter

K. M. Krupka

W. L. Kuhn

D. E. Larson

J. L. McElroy/

R. E. Nightingale

G. L. McVay

R. D. Nelson/W. A. Ross/ 0. F. Hil1

C. R. Palmer/R. 0. Lokken/ A. D. Chockie/

G. B. Mellinger

A. M. Platt

R. A. Peters

D. Rai

J. F. Relyea

J. M. Rusin/R. P. May

J. L. Ryan

R. J. Serne

J. W. Shade

J. A. Stottlemyre

R. G. Strickert

J. L. Swanson

R. P. Turcotte/D. M. Strachen

R. W. Westerman

E. J. Whee lwr ight

Water and Land Resources

Library (10)

Technical Information

Library (5)

Publishing Coordination (2) 


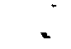

